\title{
A botanical from the antiproliferative Cameroonian spice, Imperata cylindrica is safe at lower doses, as demonstrated by oral acute and sub-chronic toxicity screenings
}

\author{
Paul Nayim, Armelle T. Mbaveng ${ }^{*}$, Arsene M. Ntyam and Victor Kuete*
}

\begin{abstract}
Background: The cytotoxicity of the root's methanol extract of Imperata cylindrica (ICR). was previously reported in a panel of human cancer cell lines, including multi-drug resistant phenotypes. The aim of this study was to assess the acute and sub-chronic oral toxicity of methanol root extract of Imperata cylindrica.

Methods: The acute toxicity was carried out according to the experimental protocol of OECD. The plant extract was administered orally to female rats at a single dose of $5000 \mathrm{mg} / \mathrm{kg}$ for 14 days and the animals were observed for any behavioral changes or mortality. For sub-chronic toxicity study, ICR was orally administered daily to male and female rats at different doses $(250,500$ and $1000 \mathrm{mg} / \mathrm{kg}$ per b.w.) for 30 days. During these treatment days the animals were observed for any appearance of toxicity symptoms; following the treatment period, animals were sacrificed for hematological, biochemical and histopathology analysis.

Results: From the results of the acute oral toxicity assay, ICR was found to be non-toxic at the dose of $5000 \mathrm{mg} / \mathrm{kg}$ b.w. During the period of sub-chronic toxicity test, observation of signs, behavior and health status of the animals showed no abnormality in the groups of animals treated with ICR as compared to the controls. Significant variation of the relative body weights of heart and kidney were observed at dose a $1000 \mathrm{mg} / \mathrm{kg} \mathrm{b.w.} \mathrm{Significant} \mathrm{decrease} \mathrm{of}$ aspartate aminotransferase, creatinine level, low density lipoprotein concentration, triglyceride and total cholesterol were observed. In males, we noticed a significant decrease of the level of granulocytes with an increase of lymphocytes and mean corpuscular hemoglobin concentration levels. Histological examinations performed on kidney and liver showed a normal kidney architecture and liver also presented a normal hepatic architecture with slight degeneration at a dose $1000 \mathrm{mg} / \mathrm{kg}$ b.w.

Conclusion: ICR is safe for acute oral administration; however, for long-term oral administration, safety measures should be taken. Thus, oral sub-chronic exposure of ICR at lower doses are recommended while higher doses around $1000 \mathrm{mg} / \mathrm{kg}$ b.w. should be discouraged.
\end{abstract}

Keywords: Imperata cylindrica, Root methanol extract, Acute toxicity, Sub-chronic toxicity

\footnotetext{
*Correspondence: armbatsa@yahoo.fr; kuetevictor@yahoo.fr

Department of Biochemistry, Faculty of Science, University of Dschang,

Dschang, Cameroon
}

\section{$\triangle B M C$}

(c) The Author(s). 2020 Open Access This article is licensed under a Creative Commons Attribution 4.0 International License, which permits use, sharing, adaptation, distribution and reproduction in any medium or format, as long as you give appropriate credit to the original author(s) and the source, provide a link to the Creative Commons licence, and indicate if changes were made. The images or other third party material in this article are included in the article's Creative Commons licence, unless indicated otherwise in a credit line to the material. If material is not included in the article's Creative Commons licence and your intended use is not permitted by statutory regulation or exceeds the permitted use, you will need to obtain permission directly from the copyright holder. To view a copy of this licence, visit http://creativecommons.org/licenses/by/4.0/ The Creative Commons Public Domain Dedication waiver (http://creativecommons.org/publicdomain/zero/1.0/) applies to the data made available in this article, unless otherwise stated in a credit line to the data. 


\section{Background}

The fight against many human diseases mainly requires research and discovery of therapeutic substances; the latter may be derived from the animal kingdom as well as the plant kingdom. Plants synthesize certain class of chemical substances during their growth to resist against environmental stress, and some of those substances are used to cure human and animal diseases [1-3]. The rhizomes of $I$. cylindrica have been used as diuretic, anti-inflammatory or antipyretic agent in traditional herbal medicine [4]. Also, numerous studies had already shown biological effects of several medicinal plants towards human and animal diseases, such as Imperata cylindrica for its antibacterial [5], antifungal [6], anti-trypanosome [7] and anti-cancer activity. The cytotoxicity of ICR was previously reported in a panel of human cancer cell lines, including multi-drug resistant phenotypes; the methanol extract of this plant has been shown to induce apoptosis in leukemia CCRF-CEM cells, mediated by the alteration of mitochondrial membrane potential [8]. According to in vitro studies done on the leaf extract of Imperata cylindrica, this plant affects the proliferation of oral squamous cell carcinoma cell line SCC-9 through apoptosis induction [9]; also, investigations of Kwok et al. showed the cytotoxic and pro-oxidative effects of Imperata cylindrica aerial part ethyl acetate extract in colorectal cancer [10]. The methanol extract of the roots has been reported for its fascinating cytotoxic effects towards a panel of human cancer cell lines, including multidrug resistant phenotypes [11]. These cell lines included CCRF-CEM, CEM/ADR5000, HL60 and HL60AR leukemia cell lines, MDA-MB231 and MDAMB231/BCRP breast adenocarcinoma cell line, HCT116 $p 53^{+/+}$and HCT116 $p 53^{-/-}$colon carcinoma cell line, U87MG, and U87MG. $E$ EGFR gliobastoma cell line, HepG2 hepatocarcinoma cell line and Mia Paca2 pancreatic cancer cell line $[8,10]$. Many compounds with biological properties had been isolated from the rhizomes of $I$. cylindrica such as arundoin, cylindrin, fernenol, cylindol, cylindrene, graminones and imperanene [12-14]. Despite their pharmacological properties, plants can also be harmful for human health. In addition, some chemical or secondary metabolites produced by plant are toxins like substances, they may cause problems to humans or animals. They have both useful and harmful effects in human beings and animals [15]. They act in animal or human body using varying specific mechanisms involving receptors, transporters, enzymes and even genetic materials at specific cells and tissues [16]. The poisonous part of the plant can be the seed, root, leaf, stalk, fruit or the whole plant whereby even a relatively small amount either taken or administered can be harmful to the human body; however, the doses of these substances are the most important factor [15]. So, despite the biological activity exhibited by certain plants, the study of their toxicity remains particularly important. The present study was devoted to evaluating the acute and subchronic oral toxicity of the root's methanol extract of Imperata cylindrica on experimental animals.

\section{Methods \\ Animals}

We used young healthy males and females albino Wistar rats, nulliparous and non-pregnant, aged between 8 to 12 weeks maximum, we obtained these animals at the Animal house of the Biochemistry Department of the University of Dschang. These rats were randomly selected and kept in their cages five days before the onset of the tests for their acclimation to the laboratory conditions. The temperature of the experimental room was maintained at $22{ }^{\circ} \mathrm{C}\left( \pm 3{ }^{\circ} \mathrm{C}\right)$, artificial lighting was provided, alternating sequences of $12 \mathrm{~h}$ of darkness; the animals were housed in individual cages and fed with standard rat diet ad libitum and were allowed free access to water. The experimental protocols used for this study were approved by the Local Ethical Committee of the Faculty of Science (University of Dschang - Cameroon) and were designed in concordance with the internationally accepted standard ethical guidelines for laboratory animals use and care as described in the guidelines of the European Union Institutional Ethics Committee on Animal Care (Council EEC 86/609/EEC of the 24th November 1986). All sections of this report adhere to the ARRIVE Guidelines for reporting animal research [17] (Additional file 1). A completed ARRIVE guidelines checklist is included in Checklist S1.

\section{Plant material and extract preparation}

The roots of the plant used in this study were harvested at a field the West-Cameroon Region of Cameroon ("Menoua" Division) after the approval of the research project by the University of Dschang (Faculty of Science). A sample of this plant has been identified and authenticated by Mr. NANA Victor at the National Herbarium of Cameroon (Yaounde) as Imperata cylindrica (L.) Raeusch (Gramineae) under the voucher number 30139/SRF-Cam.

The roots of Imperata cylindrica were dried and ground, the resulting powder was macerated using methanol $(1,3 \mathrm{w} / \mathrm{v})$ at room temperature for $48 \mathrm{~h}$. The mixture was stirred about 3 to 4 times per day to maximize yield. It was then filtered with Wattman $\mathrm{N}^{\circ} 1$ paper and the filtrate obtained was evaporated using a rotary evaporator (BÜCHI R - 200) at $65^{\circ} \mathrm{C}$. The crude extract was recovered in a sterile vial and dried in an oven at $40{ }^{\circ} \mathrm{C}$ until the solvent completely evaporated. 


\section{Acute oral toxicity study}

Acute toxicity assessment of Imperata cylindrica was carried out according to the experimental protocol proposed by OECD Guideline 425 [18]. We performed the test at $5000 \mathrm{mg} / \mathrm{kg} \mathrm{b.w}$. of ICR. We had two experimental groups both made up of female rats: test group $(n=5)$ and control group $(n=5)$. The animals were kept under food depravation (removal of food, but not water) the day before the oral administration of the extract. After the fasting period, we weighed the rats and the plant extract was administered by gavage to animals at a single dose as mentioned above. Doses were calculated based on the fasting body weight of each animal. After administration of the extract, the rats were deprived from food for $4 \mathrm{~h}$. The medium lethal dose $\left(\mathrm{LD}_{50}\right)$ value was recorded $48 \mathrm{~h}$ after the extract was administered. The rats were observed individually with particular attention during the first $4 \mathrm{~h}$ after gavage and regularly during the first $24 \mathrm{~h}$ and then daily for 14 days during which physical symptoms of toxicity such as sensitivity to pain, motor activity by observing movements within the cage, noise sensitivity, tooth grinding and faeces appearance, tremors, drowsiness and convulsions. After these 14 days of observation, each animal was sacrificed to detect possible macroscopic pathological changes on organs such as the liver, kidneys, lungs and heart. The organs of the animal's test group were compared to those of control group [18, 19].

\section{Sub-chronic oral toxicity study}

In order to obtain information on repeated oral exposure to ICR, we assessed the sub-chronic toxicity of this plant according to the OECD Guideline No. 407 for chemical testing [20].

Nulliparous and non-pregnant Wistar rats aged between 8 to 12 weeks were divided into four groups of 10 rats per group, including 5 males and 5 females. Animals of the control group (group 1) received the vehicle daily (water + Tween 5\%) while those of the remaining three test groups, that is group 2,3 and 4 received plant extract by oral gavage at doses 250,500 and $1000 \mathrm{mg} / \mathrm{kg}$ b.w per day respectively. The animals were fed with standard rat diet ad libitum and were allowed free access to water. After the test period expired (30 days), we proceeded to animals sacrifice: the animals were anesthetized through intra-peritoneal injection of a cocktail containing ketamine $(100 \mathrm{mg} / \mathrm{Kg})$ and xylazine $(12 \mathrm{mg} / \mathrm{Kg})$ [ratio 10:1] for an $1 \mathrm{~h}$.

\section{Collection of blood samples}

After general anesthesia of animals, blood samples were collected: the animals were placed in supine position, the abdominal cavity opened, the intestines moved to the left, the abdominal aorta was located,
$10 \mathrm{ml}$ syringe needle was inserted at the base of the aorta and immediately the maximum amount of blood was collected and the animals death verified [21]. As soon as the blood sample was collected, it was separated in two parts; one part of the blood for haematological analyses, collected in tubes coated with ethylene diamine tetra-acetic acid (EDTA) and the other part of the blood was collected in tubes without anticoagulants and used for biochemical analyses. Blood samples for evaluation of biochemical parameters were kept at room temperature for $1 \mathrm{~h}$ to allow coagulation; they were then centrifuged at 300 $\mathrm{rpm}$ for $10 \mathrm{~min}$. The serum obtained was introduced into eppendorf tubes and stored at $-25^{\circ} \mathrm{C}$ for future use.

\section{Evaluation of haematological parameters}

Blood samples collected in the EDTA tubes were used to perform blood count using an impedance hematology machine (QBC Auto-read Plus, United Kingdom). The hematological parameters analyzed included leukocytes, neutrophils, eosinophils, basophils, lymphocytes and monocytes counts; red blood cells (RBC), hemoglobin $(\mathrm{Hb})$, mean corpuscular volume (MCV); mean corpuscular hemoglobin $(\mathrm{MCH})$, mean corpuscular hemoglobin concentration (MCHC), platelets (PLT), Hematocrit (HCT), Mean corpuscular volume (MCV), Mean corpuscular Haemoglobin $(\mathrm{MCH})$, Mean corpuscular Haemoglobin concentration (MCHC), Red blood cells distribution width $\mathrm{CV}$, Red blood cells distribution width SD.

\section{Assessment of biochemical parameters}

In this study, we explored the following biochemical parameters: aspartate aminotransferase (AST), alanine aminotransferase (ALT), proteins, urea, creatinine, total cholesterol (TC), high density lipoprotein (HDL), low density lipoprotein (LDL), triglyceride (TG). Handling was carried out according to the protocol of the kit manufacturer.

\section{Histology}

After the animals were sacrificed, the heart, liver, lungs, spleen and kidneys were collected and weighed but only the liver and the kidney were used for histological analyses [22]. Collected organs were washed in a $0.9 \% \mathrm{NaCl}$ solution and immediately preserved in $10 \%$ formaldehyde, dehydrated with alcohol; $5 \mu \mathrm{m}$ thick cuts were made using a microtome and stained with hematoxylin eosin. These colored sections were covered with a thin glass plate and observed under an optical microscope equipped with a camera (400X) for taking photographs. A comparative histopathological study of the organs was performed. 


\section{Statistical analysis}

Data from each experimental group was expressed as mean \pm SEM. One-way analysis of variance (ANOVA) followed by Dunnett's post-hoc test for multiple comparisons were used for statistical analysis of data using GraphPad Prism software version 5.01. Differences were considered significant at a probability level of $5 \%(p<0.05)$.

\section{Results}

\section{Acute toxicity study}

Acute toxicity assessment of ICR was to determine the dose at which it kills the $50 \%$ of test animals $\left(\mathrm{LD}_{50}\right)$ and the highest dose for which no toxic effects is observed in relation to the control lot. Forty-eight hours $(48 \mathrm{H})$ after administration of the single dose of $5000 \mathrm{mg} / \mathrm{kg}$ b.w. of ICR, we did not record any animal deaths neither during the 14 days of monitoring and observation. Immediately after the extract administration, some animals experienced agitation and drowsiness; however, these signs disappeared within few minutes. Thus, the $\mathrm{LD}_{50}$ of ICR was estimated to be greater than $5000 \mathrm{mg} / \mathrm{kg}$ b.w.

\section{Sub-chronic toxicity study}

Throughout the test period (30 days), at the different extract doses, no visible sign of toxicity was observed in both the males and the females test and control groups.

\section{Effects of oral administration of ICR on body weights and} relative organ weights

Figures 1 and 2 summarize the evolution of animal body weights both in females and males, respectively. Overall after the five (05) weeks of the test, we observed in all groups, an increase of rat body weights with a slight non-significant decrease of body weights both for male and female rats treated with $500 \mathrm{mg} / \mathrm{kg}$ b.w. in the last week of the test.

Tables 1 and 2 present the relative organ weights of the control group animals and those of rats treated with ICR at different doses (250, 500 and $1000 \mathrm{mg} / \mathrm{kg}$ b.w.) in females and males respectively. All females of the test groups showed a non-significant decrease $(p<0.05)$ of relative masses of organs such as the heart and spleen compared to the control group. In males, there was a significant increase $(\mathrm{p}<0.05)$ of the relative weight of heart in rats treated with $1000 \mathrm{mg} / \mathrm{kg}$ b.w. compared to controls. We also noticed a significant increase $(p<0.05)$ of kidney relative weigh in test group rats at 500 and $1000 \mathrm{mg} / \mathrm{kg}$ b.w.

\section{Effects of oral administration of ICR on biochemical parameters}

Tables 3 and 4 present the results of biochemical parameters for animals of the control group and for those of animals treated at different doses of ICR (250, 500 and $1000 \mathrm{mg} / \mathrm{kg}$ b.w.) for females and males respectively. We noted a significant decrease $(p<0.05)$ of urinary creatinine concentration in both females and males treated with ICR at $500 \mathrm{mg} / \mathrm{kg}$ b.w.

Whereas compared to control group, we also noted a significant decrease $(\mathrm{p}<0.05)$ of the level of aspartate aminotransferase in all male and female rats treated with ICR at different test doses $(250,500$ and $1000 \mathrm{mg} / \mathrm{kg}$ b.w.).

Effects of oral administration of ICR on serum lipid profile Tables 5 and 6 present the lipid profiles of the animals in the control group and those treated with ICR at different doses $(250,500$ and $1000 \mathrm{mg} / \mathrm{kg}$ b.w.) in females

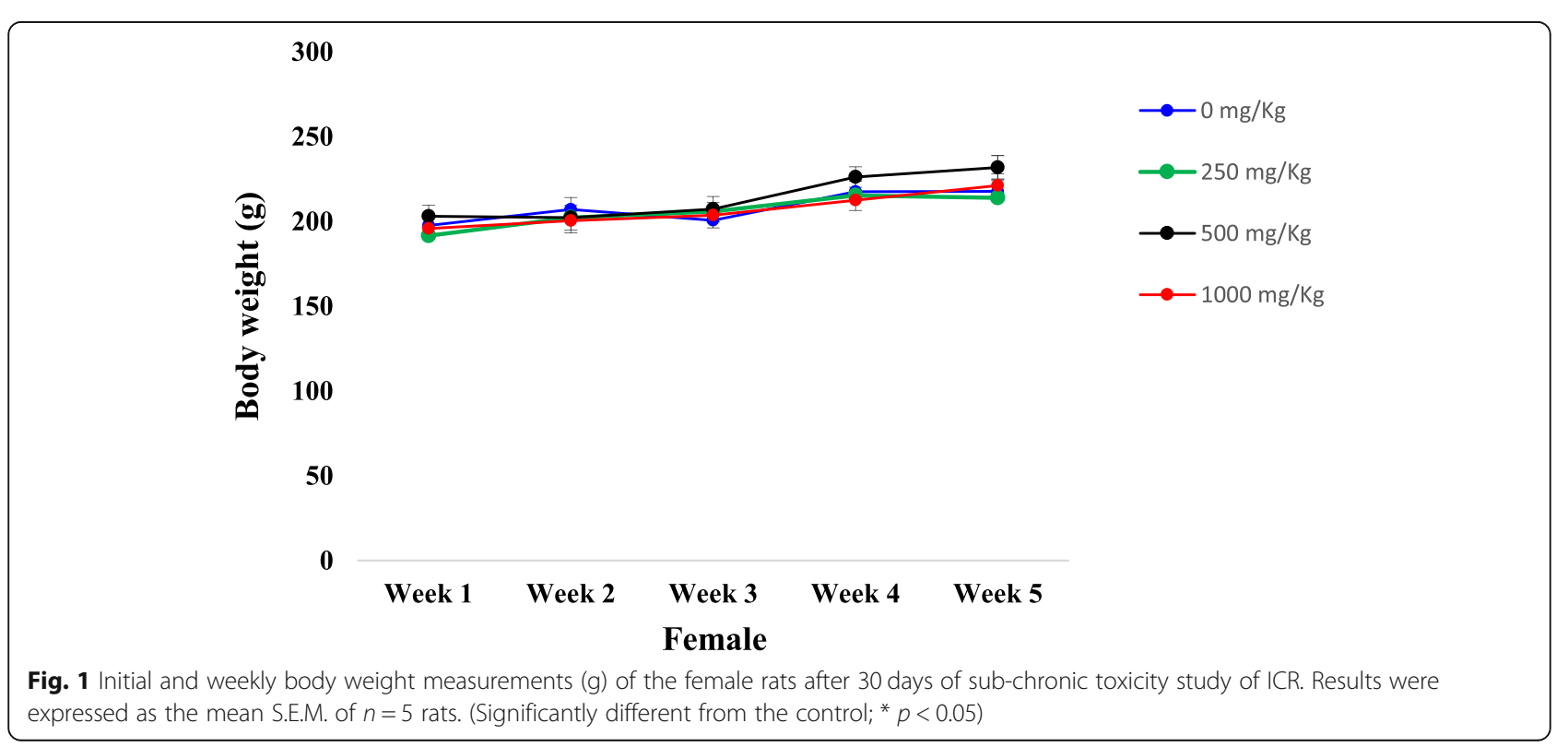




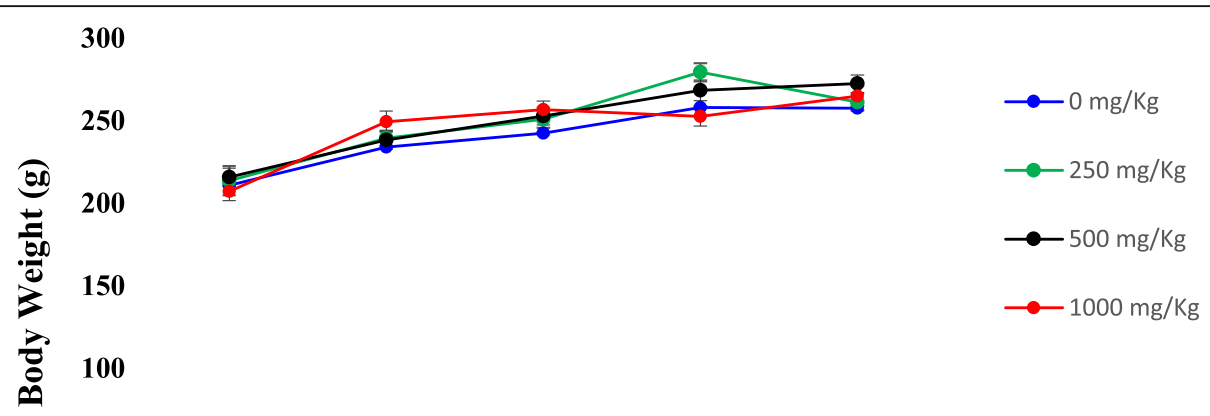

50

0

\begin{tabular}{|c|c|c|c|c|}
\hline Week 1 & Week 2 & & Week 4 & Week 5 \\
\hline
\end{tabular}

Fig. 2 Initial and weekly body weight measurements (g) of the male rats after 30 days of sub-chronic toxicity study of the ICR. Results were expressed as the mean S.E.M. of $\mathrm{n}=5$ rats. (Significantly different from the control; * $p<0.05$ )

and males, respectively. In females, compared to the control group, we did not notice any significant variation in lipid profile in animals treated with ICR; a similar observation was made in males' rats. We observed a significant decrease of the concentration of low-density lipoprotein (LDL) in the group of animals treated with ICR at $250 \mathrm{mg} /$ $\mathrm{kg}$ b.w. and a slight non-significant increase in total cholesterol (TC) and triglyceride (TG) levels.

\section{Effects of oral administration of ICR on hematological parameters}

Tables 7 and 8 present the hematological profiles of animals in the control group and those treated with ICR at different doses (250, 500 and $1000 \mathrm{mg} / \mathrm{kg}$ b.w.) in females and males, respectively. Males treated with ICR at 500 and $1000 \mathrm{mg} / \mathrm{kg}$ b.w. showed a significant increase $(p<0.05)$ in lymphocyte and MCHC levels; we also noted that females treated with the same doses of ICR showed a significant increase $(p<0.05)$ in PLT levels compared to the control groups. In all groups of females treated with ICR, there was a significant decrease $(p<0.05)$ in granulocyte levels; while in males, there was a significant increase $(\mathrm{p}<0.05)$ in granulocyte levels compared to the control groups.

\section{Histopathological examination}

Histopathological examinations were performed on the liver and the kidney to assess whether organs or tissues had been damaged. The kidney of treated rats showed normal glomeruli and there was no necrosis of tubular epithelium in both the females (Fig. 3) and the males (Fig. 4) treated rats. The liver appeared normal with preserved hepatic architecture; however, slight degeneration (lesions) were occasionally observed in both the females (Fig. 5) and the males (Fig. 6) treated at the highest dose of ICR as compared to the control group.

\section{Discussion}

The use of medicinal plants in the treatment of human diseases is not only assured by their identified biological properties, but also by the demonstration of their harmlessness to human cells. Numerous investigations on ICR have already highlighted its various pharmacological properties [5-10]. Several studies showed the antiproliferative activity of various parts of ICR against a

Table 1 Effects of sub-chronic oral administration of ICR on relative organs weights of females rats

\begin{tabular}{lllll}
\hline Females & \multicolumn{1}{l}{ ICR (mg/kg b.w.) } & & \\
\cline { 2 - 4 } & Control & 250 & 300 & 1000 \\
\hline Liver & $3.442 \pm 0.348$ & $3.510 \pm 0.350^{\mathrm{ns}}$ & $3.562 \pm 0.167^{\mathrm{ns}}$ & $0.247^{\mathrm{ns}}$ \\
Heart & $0.333 \pm 0.017$ & $0.291 \pm 0.001^{\mathrm{ns}}$ & $0.314 \pm 0.017^{\mathrm{ns}}$ & $0.328 \pm 0.025^{\mathrm{ns}}$ \\
Lungs & $0.630 \pm 0.094$ & $0.652 \pm 0.024^{\mathrm{ns}}$ & $0.646 \pm 0.086^{\mathrm{ns}}$ & $0.701 \pm 0.123^{\mathrm{ns}}$ \\
Spleen & $0.405 \pm 0.103$ & $0.364 \pm 0.024^{\mathrm{ns}}$ & $0.362 \pm 0.023^{\mathrm{ns}}$ & $0.365 \pm 0.003^{\mathrm{ns}}$ \\
Kidney & $0.650 \pm 0.007$ & $0.646 \pm 0.033^{\mathrm{ns}}$ & $0.649 \pm 0.034^{\mathrm{ns}}$ & $0.646 \pm 0.015^{\mathrm{ns}}$ \\
\hline
\end{tabular}

Results were expressed as Mean \pm SEM for $n=5$ animals per group. Significantly different from the control at $p<0.05$; ns: non significative; ICR: methanol extract of the roots of Imperata cylindrica 
Table 2 Effects of sub-chronic oral administration of ICR on relative organ weights of males rats

\begin{tabular}{|c|c|c|c|c|}
\hline \multirow[t]{2}{*}{ Males } & \multicolumn{4}{|c|}{ ICR (mg/kg b.w.) } \\
\hline & \multicolumn{4}{|c|}{ Control 2,505,001,000 } \\
\hline Liver & $3.117 \pm 0.224$ & $3.244 \pm 0.314^{\mathrm{ns}}$ & $3.173 \pm 0.138^{\mathrm{ns}}$ & $3.485 \pm 0.098^{\mathrm{ns}}$ \\
\hline Heart & $0.283 \pm 0.008$ & $0.293 \pm 0.022^{\mathrm{ns}}$ & $0.311 \pm 0.013^{\mathrm{ns}}$ & $0.333 \pm 0.016^{*}$ \\
\hline Lungs & $0.595 \pm 0.056$ & $0.650 \pm 0.015^{\mathrm{ns}}$ & $0.566 \pm 0.030^{\mathrm{ns}}$ & $0.656 \pm 0.059^{n s}$ \\
\hline Spleen & $0.355 \pm 0.031$ & $0.325 \pm 0.010^{\mathrm{ns}}$ & $0.392 \pm 0.049^{\mathrm{ns}}$ & $0.338 \pm 0.013^{n s}$ \\
\hline Kidney & $0.604 \pm 0.003$ & $0.618 \pm 0.020^{\mathrm{ns}}$ & $0.657 \pm 0.020^{*}$ & $0.654 \pm 0.023^{*}$ \\
\hline
\end{tabular}

Results were expressed as Mean \pm SEM for $n=5$ animals per group. ${ }^{*}$ :Significantly different from the control at $p<0.05$; ns: non significative; ICR: methanol extract of the roots of Imperata cylindrica

panel of human cancer cell lines, including multi-drug resistant phenotypes [8-10]. But up till date, no literature has reported toxicological studies on the methanol extract of the roots of this plant; hence our interest in undertaken the study of the acute and sub-chronic toxicity of ICR in order to contribute to its safe use in the management of certain human diseases.

In this study, acute oral toxicity was achieved by administering single dose of $5000 \mathrm{mg} / \mathrm{Kg}$ b.w. in females. At this dose, there were no lethality and no clinical signs of acute toxicity. The lethal dose $50\left(\mathrm{LD}_{50}\right)$ of ICR would therefore be higher than $5000 \mathrm{mg} / \mathrm{Kg}$ b.w., and this result correlates investigations done by Chunlaratthanaphorn [23] on the aqueous extract of this same plant which also indicated an $\mathrm{LD}_{50}$ higher than $5000 \mathrm{mg} / \mathrm{Kg}$ b.w.

The sub-chronic toxicity of ICR was realized by repeated oral administration of 250, 500 and $1000 \mathrm{mg} / \mathrm{Kg}$ b.w. for 30 days.

After 30 days of treatment, weight gains were higher in the test groups than in the control group. Significant increase $(p<0.05)$ in the relative weight of the heart in rats treated with $1000 \mathrm{mg} / \mathrm{Kg} \mathrm{b.w.} \mathrm{and}$ equally significant increase $(p<0.05)$ of the relative weight of the kidney for the rats treated with 500 and $1000 \mathrm{mg} / \mathrm{Kg}$ b.w. could be correlated with a possible toxic effect of the plant at these doses since the kidney is one of the main organs involved in the elimination of xenobiotics in the body [24], but the histological sections of the kidney observation did not reveal any morphological alteration of this organ so this hypothesis is thus rejected.

The liver and kidneys are targeted organs for chemicals (drugs and poisons) because of their role in the detoxification and excretion processes of the body. These organs are extremely useful for toxicity studies because of their sensitivity to harmful compounds and their potential to predict possible toxicity. Changes in the weight of these vital organs related to toxicity are frequently accompanied by histopathological modifications. However, changes in the weight of certain organs such as the lungs, heart and spleen have less impact on toxicity because of their limited role in eliminating harmful substances from the body $[25,26]$.

Histopathological examinations performed on liver and kidney of treated and controls rats showed a normal kidney architecture and a liver with preserved hepatic architecture. The slight degeneration observed at the highest dose of ICR as compared to the control could be due to the toxic effect of this plant since drug/chemicalmediated hepatic injury is the most common manifestation of drug toxicity [27].

The analysis of serum and urinary biochemical parameters during toxicity studies provides important information on the functioning of specific tissues of the body

Table 3 Effects of sub-chronic oral administration of ICR on serum and urinary biochemical parameters in females rats

\begin{tabular}{|c|c|c|c|c|}
\hline \multirow[t]{2}{*}{ Females } & \multicolumn{4}{|l|}{ ICR (mg/kg b.w.) } \\
\hline & Control & 250 & 500 & 1000 \\
\hline Serum creatinine $(\mu \mathrm{mol} / \mathrm{l})$ & $53.670 \pm 3.969$ & $46.300 \pm 4.210^{\mathrm{ns}}$ & $52.620 \pm 2.977^{\mathrm{ns}}$ & $48.41 \pm 3.930^{\mathrm{ns}}$ \\
\hline Urinary creatinine $(\mu \mathrm{mol} / \mathrm{l})$ & $1049 \pm 67.97$ & $1159 \pm 52.730^{\text {ns }}$ & $475.600 \pm 44.200^{*}$ & $994.900 \pm 55.250^{\text {ns }}$ \\
\hline Serum urea $(\mathrm{mmol} / \mathrm{L})$ & $6.733 \pm 0.026$ & $6.113 \pm 0.733^{\mathrm{ns}}$ & $3.455 \pm 0.131^{\mathrm{ns}}$ & $6.762 \pm 0.7427^{\mathrm{ns}}$ \\
\hline Urinary urea (mmol/L) & $10.739 \pm 0.024$ & $11.46 \pm 1.260^{\mathrm{ns}}$ & $12.100 \pm 0.5764^{\mathrm{ns}}$ & $12.080 \pm 0.8529^{\mathrm{ns}}$ \\
\hline Serum total protein $(g / L)$ & $44.800 \pm 0.034$ & $43.300 \pm 0.062^{\mathrm{ns}}$ & $34.500 \pm 0.056^{\mathrm{ns}}$ & $42.300 \pm 0.007^{\mathrm{ns}}$ \\
\hline Urinary total protein (g/L) & $7.239 \pm 0.277$ & $6.800 \pm 0.036^{\mathrm{ns}}$ & $7.687 \pm 0.241^{\mathrm{ns}}$ & $6.606 \pm 0.434^{\mathrm{ns}}$ \\
\hline ALT (U/L) & $33.350 \pm 1.521$ & $31.650 \pm 2.260^{\mathrm{ns}}$ & $35.200 \pm 1.218^{n s}$ & $31.830 \pm 1.701^{\mathrm{ns}}$ \\
\hline AST (U/L) & $74.740 \pm 3.420$ & $58.220 \pm 2.019^{*}$ & $58.270 \pm 2.399^{*}$ & $52.100 \pm 2.895^{*}$ \\
\hline
\end{tabular}

Results were expressed as Mean \pm SEM for $n=5$ animals per group. *:Significantly different from the control at $p<0.05$ 
Table 4 Effects of sub-chronic oral administration of ICR on serum and urinary biochemical parameters in males rats

\begin{tabular}{lllll}
\hline Females & \multicolumn{1}{l}{ ICR $(\mathrm{mg} / \mathrm{kg}$ b.w.) } & & \\
\cline { 2 - 5 } & Control & 250 & 500 & 1000 \\
\hline Serum creatinine $(\boldsymbol{\mu m o l} / \mathbf{l})$ & $50.510 \pm 1.500$ & $46.300 \pm 1.607^{\mathrm{ns}}$ & $53.910 \pm 1.730^{\mathrm{ns}}$ & $51.560 \pm 1.814^{\mathrm{ns}}$ \\
Urinary creatinine $(\boldsymbol{\mu m o l} / \mathbf{l})$ & $1088 \pm 48.620$ & $1079 \pm 40.040^{\mathrm{ns}}$ & $670.100 \pm 30.000^{*}$ & $1091 \pm 50.730^{\mathrm{ns}}$ \\
Serum urea $(\mathbf{m m o l} / \mathbf{L})$ & $5.650 \pm 0.147$ & $5.524 \pm 0.175^{\mathrm{ns}}$ & $5.697 \pm 0.065^{\mathrm{ns}}$ & $6.097 \pm 0.336^{\mathrm{ns}}$ \\
Urinary urea (mmol/L) & $25.180 \pm 0.254$ & $22.690 \pm 0.221^{\mathrm{ns}}$ & $24.490 \pm 0.689^{\mathrm{ns}}$ & $15.180 \pm 0.261^{\mathrm{ns}}$ \\
Serum total protein (g/L) & $45.300 \pm 0.036$ & $48.300 \pm 0.044^{\mathrm{ns}}$ & $44.900 \pm 0.016^{\mathrm{ns}}$ & $38.100 \pm 0.026^{\mathrm{ns}}$ \\
Urinary total protein (g/L) & $5.856 \pm 0.059$ & $6.271 \pm 0.524^{\mathrm{ns}}$ & $5.723 \pm 0.193^{\mathrm{ns}}$ & $5.395 \pm 0.357^{\mathrm{ns}}$ \\
ALT (U/L) & $34.630 \pm 2.014$ & $33.120 \pm 2.365^{\mathrm{ns}}$ & $32.00 \pm 2.000^{\mathrm{ns}}$ & $31.730 \pm 2.026^{\mathrm{ns}}$ \\
AST (U/L) & $68.770 \pm 2.918$ & $54.490 \pm 2.258^{*}$ & $42.940 \pm 2.029^{*}$ & $50.080 \pm 1.747^{*}$ \\
\hline
\end{tabular}

Results were expressed as Mean \pm SEM for $n=5$ animals per group. * :Significantly different from the control at $p<0.05$

ALT Alanine aminotransferase, AST Aspartate aminotransferase, ns non significative, ICR methanol extract of the roots of Imperata cylindrica

such as the liver and kidneys that are highly involved in the metabolism and excretion of plant extracts that are mixtures of chemicals [28]. Apart from Aspartate aminotransferase and urinary creatinine, we did not find any other significant variations of the other biochemical parameters in the ICR treated groups compared to the control groups.

A significant decrease $(p<0.05)$ of aspartate aminotransferase levels we observed in all male and female animals treated with ICR at different doses (250, 500 and $1000 \mathrm{mg} / \mathrm{Kg}$ b.w.). Similar results were obtained by Chunlaratthanaphorn [23], who showed the ability of the aqueous extract of Imperata cylindrica to induce a decrease in AST levels at a dose $1200 \mathrm{mg} / \mathrm{Kg}$ b.w. Regarding ALT concentrations, we did not noted any significant variations within all group tests, and based on these results, ICR would not affect the proper functioning of the liver because following acute hepatocellular injury, there will be moderate to marked increase in both serum ALT and AST even though ALT is more reliable to detect for both acute and sub-acute hepatocellular injuries [29]. The serum hepatic leakage enzymes include alanine aminotransferase (ALT), aspartate aminotransferase (AST), sorbital dehydrogenase and glutamate dehydrogenase. Following hepatocellular injury or alterations in liver membrane permeability, these enzymes leak out of the membrane into peripheral blood. However, for practical purposes ALT and AST are currently widely used to assess liver functions [30].

Creatinine is a waste product that is produced by the muscles through normal contraction. Serum creatinine levels are constant and proportional to the muscle mass. Creatinine is excreted from the body through the kidneys. Then creatinine provides a good measure of how well the kidneys are working. In this study, we noted a significant decrease $(p<0.05)$ in urinary creatinine concentration in females and males treated with ICR at 500 $\mathrm{mg} / \mathrm{kg}$ b.w. A low urine creatinine level could indicate reduced kidney function, but however, a factor like improper urine collection may also affect urine creatinine level [31]. With the exception of a significant decrease in LDL (low density lipoprotein) in the group of animals treated with ICR at $250 \mathrm{mg} / \mathrm{Kg}$ b.w., a slight non-significant increase of the total cholesterol (TC) and triglyceride (TG) was observed in groups of animals treated with 250 $\mathrm{mg} / \mathrm{kg}$, all other groups of animals treated with ICR showed a normal lipid profile compared to the control group. LDL cholesterol (low density lipoprotein) is a fat essential for the proper functioning of the body. LDL is also known as bad cholesterol because its increase is linked to an increase in cardiovascular risk. The decrease of this particular lipid level by ICR confirms the results of the work of Mak-Mensah et al. [32], Rouslin et al. [33] and Sulistyowati et al. [34] which showed that the plant

Table 5 Effects of sub-chronic oral administration of ICR on the lipid profile of females rats

\begin{tabular}{lllll}
\hline Females & \multicolumn{1}{l}{ ICR (mg/kg b.w.) } & & \\
\cline { 2 - 5 } & Control & 250 & 500 & 1000 \\
\hline TC (mmol/L) & $1.158 \pm 0.173$ & $1.699 \pm 0.161^{\mathrm{ns}}$ & $1.521 \pm 0.172^{\mathrm{ns}}$ & $1.337 \pm 0.167^{\mathrm{ns}}$ \\
TG (mmol/L) & $1.059 \pm 0.141$ & $0.843 \pm 0.100^{\mathrm{ns}}$ & $1.289 \pm 0.175^{\mathrm{ns}}$ & $0.994 \pm 0.141^{\mathrm{ns}}$ \\
HDL (mmol/L) & $0.946 \pm 0.129$ & $0.883 \pm 0.072^{\mathrm{ns}}$ & $0.809 \pm 0.077^{\mathrm{ns}}$ & $0.965 \pm 0.070^{\mathrm{ns}}$ \\
LDL (mmol/L) & $0.430 \pm 0.023$ & $0.442 \pm 0.025^{\mathrm{ns}}$ & $0.399 \pm 0.0009^{\mathrm{ns}}$ & $0.378 \pm 0.045^{\mathrm{ns}}$ \\
\hline
\end{tabular}

Results were expressed as Mean \pm SEM for $\mathrm{n}=5$ animals per group. ${ }^{*}$ :Significantly different from the control at $p<0.05$; TC: Total cholesterol; TG: Total triglyceride; HDL: High density lipoprotein; LDL: Low density lipoprotein; ns: non significative; ICR: methanol extract of the roots of Imperata cylindrica 
Table 6 Effects of sub-chronic oral administration of ICR on the lipid profile of males rats

\begin{tabular}{lllll}
\hline Males & ICR (mg/kg b.w.) & & \\
\cline { 2 - 5 } & Control & 250 & 500 & 1000 \\
\hline TC (mmol/L) & $1.499 \pm 0.100$ & $1.699 \pm 0.008^{\mathrm{ns}}$ & $1.876 \pm 0.062^{\mathrm{ns}}$ & $1.378 \pm 0.034^{\mathrm{ns}}$ \\
TG (mmol/L) & $1.167 \pm 0.072$ & $1.21 \pm 0.028^{\mathrm{ns}}$ & $1.435 \pm 0.221^{\mathrm{ns}}$ & $1.248 \pm 0.157^{\mathrm{ns}}$ \\
HDL (mmol/L) & $2.193 \pm 0.088$ & $2.13 \pm 0.052^{\mathrm{ns}}$ & $2.425 \pm 0.034^{\mathrm{ns}}$ & $2.043 \pm 0.199^{\mathrm{ns}}$ \\
LDL (mmol/L) & $0.537 \pm 0.110$ & $0.343 \pm 0.016^{*}$ & $0.5233 \pm 0.023^{\mathrm{ns}}$ & $0.645 \pm 0.024^{\mathrm{ns}}$ \\
\hline
\end{tabular}

Results were expressed as Mean \pm SEM for $n=5$ animals per group. *:Significantly different from the control at $p<0.05$

TC Total cholesterol, TG Total triglyceride, HDL High density lipoprotein, LDL Low density lipoprotein, $n s$ non significative, ICR methanol extract of the roots of Imperata cylindrica

used in this study is effective against a cardiovascular disorder such as hypertension, since it is widely accepted that hypertension is associated with an increased blood levels of low-density lipoprotein (LDL).

To determine the intravascular effect and bone marrow activity in rats treated with the extract, hematological parameters of female and male rats were examined as presented in Tables 7 and 8. Males treated with ICR at 500 and $1000 \mathrm{mg} / \mathrm{Kg}$ b.w. showed a significant increase $(p<0.05)$ of the levels of lymphocyte and $\mathrm{MCHC}$; we had also noticed that females treated with the same doses of ICR showed a significant increase $(p<0.05)$ in Platelets levels compared to the control groups. In all groups of females treated with ICR, there was a significant decrease $(\mathrm{p}<0.05)$ in granulocyte levels; while in males, there was a significant increase $(p<0.05)$ in granulocyte levels compared to the control groups. Several toxicological studies had shown that plant extracts can affect certain hematological parameters as it has been observed in this work [23, 35, 36].

Results obtained in this study may help for further animal studies using ICR. In effect, the leaf extract of this plant also displayed cytotoxic effects against cancer cells lines [9], though in-depth studies were not done as for ICR. The fact that the present investigation did not consider leaf extract and water extraction are limitations of this study. In effect, for a given plant, if both the leaves and roots present approximatively similar pharmacological activities like the case of Imperata cylindrica for their anticancer activities, for a sustainable production it is advisable to use leaves as source of drug since this would avoid the destruction of the whole plant, and moreover leaves are much more easier to get in large amount compare to roots. Hence further investigations of the toxicity of the leaf extract of Imperata cylindrica will also be performed. Nonetheless, the rationale of selecting the

Table 7 Effects of sub-chronic oral administration of ICR on the hematological profile of females rats

\begin{tabular}{|c|c|c|c|c|}
\hline \multirow[t]{2}{*}{ Females } & \multicolumn{4}{|l|}{ ICR (mg/kg b.w.) } \\
\hline & Control & 250 & 500 & 1000 \\
\hline White blood cells (X $\left.10^{3} / \mu \mathrm{L}\right)$ & $18.650 \pm 0.450$ & $15.3000 \pm 0.500^{\mathrm{ns}}$ & $17.250 \pm 1.150^{\mathrm{ns}}$ & $18.050 \pm 1.350^{\text {ns }}$ \\
\hline Lymphocytes (\%) & $82.850 \pm 1.750$ & $84.700 \pm 1.825^{\mathrm{ns}}$ & $80.570 \pm 0.602^{\mathrm{ns}}$ & $77.500 \pm 0.900^{\mathrm{ns}}$ \\
\hline Granulocytes (\%) & $14.870 \pm 1.365$ & $10.550 \pm 1.150^{*}$ & $10.430 \pm 1.629^{*}$ & $10.700 \pm 0.900^{*}$ \\
\hline Red blood cells (X $10^{6} / \mu \mathrm{L}$ ) & $7.590 \pm 0.130$ & $7.160 \pm 0.150^{\mathrm{ns}}$ & $7.340 \pm 0.100^{\mathrm{ns}}$ & $7.000 \pm 0.040^{\mathrm{ns}}$ \\
\hline Haemoglobin $(\mathrm{g} / \mathrm{dL})$ & $16.300 \pm 0.360$ & $16.130 \pm 0.585^{\mathrm{ns}}$ & $16.280 \pm 1.415^{\mathrm{ns}}$ & $15.750 \pm 0.550^{\mathrm{ns}}$ \\
\hline Hematocrit (\%) & $44.200 \pm 2.000$ & $41.130 \pm 2.573^{\mathrm{ns}}$ & $41.600 \pm 3.677^{\mathrm{ns}}$ & $41.300 \pm 1.500^{n s}$ \\
\hline Mean corpuscular volume (fL) & $61.350 \pm 1.450$ & $59.130 \pm 2.196^{\mathrm{ns}}$ & $59.050 \pm 1.150 \mathrm{~ns}$ & $59.100 \pm 1.800^{\mathrm{ns}}$ \\
\hline Mean corpuscular $\mathrm{Hb}(\mathrm{pg})$ & $21.600 \pm 0.100$ & $23.130 \pm 0.763^{\mathrm{ns}}$ & $23.100 \pm 0.585^{\mathrm{ns}}$ & $22.300 \pm 0.700^{\mathrm{ns}}$ \\
\hline $\mathrm{MCHC}(\mathrm{g} / \mathrm{dL})$ & $37.200 \pm 1.100$ & $38.300 \pm 1.200^{\mathrm{ns}}$ & $38.800 \pm 1.20^{\mathrm{ns}}$ & $38.050 \pm 0.050^{\mathrm{ns}}$ \\
\hline RDWCV (\%) & $17.570 \pm 0.717$ & $17.430 \pm 1.050^{\mathrm{ns}}$ & $17.900 \pm 1.200^{\mathrm{ns}}$ & $19.250 \pm 1.050^{\mathrm{ns}}$ \\
\hline RDWSD (fL) & $44.330 \pm 1.040$ & $43.470 \pm 1.350 \mathrm{~ns}$ & $46.00 \pm 1.500^{\mathrm{ns}}$ & $46.100 \pm 0.050^{n s}$ \\
\hline Platelets $\left(\mathrm{X} 10^{3} / \mu \mathrm{L}\right)$ & $521.00 \pm 8.900$ & $512.0 \pm 9.800^{\mathrm{ns}}$ & $824.300 \pm 6.506^{*}$ & $879.500 \pm 7.500^{*}$ \\
\hline Mean platelet volume (fL) & $11.400 \pm 0.900$ & $10.40 \pm 1.411^{\mathrm{ns}}$ & $11.470 \pm 1.305^{\mathrm{ns}}$ & $11.900 \pm 1.229^{\mathrm{ns}}$ \\
\hline Platelet distribution width ( $\mathrm{fL}$ ) & $11.770 \pm 1.002$ & $10.330 \pm 1.193^{\mathrm{ns}}$ & $10.200 \pm 0.900^{\mathrm{ns}}$ & $11.770 \pm 1.002^{\mathrm{ns}}$ \\
\hline Plateletcrit (\%) & $0.660 \pm 0.050$ & $0.585 \pm 0.165^{\mathrm{ns}}$ & $0.945 \pm 0.049^{\text {ns }}$ & $0.943 \pm 0.136^{\mathrm{ns}}$ \\
\hline
\end{tabular}

Results were expressed as Mean \pm SEM for $n=5$ animals per group. ${ }^{*}$ :Significantly different from the control at $p<0.05$

MCHC Mean corpuscular Haemoglobin concentration, RDWCV Red blood cells distribution width_CV, RDWSD Red blood cells distribution width_SD, ns non significative, ICR methanol extract of the roots of Imperata cylindrica 
Table 8 Effects of sub-chronic oral administration of ICR on the hematological profile of males rats

\begin{tabular}{|c|c|c|c|c|}
\hline \multirow[t]{2}{*}{ Males } & \multicolumn{4}{|l|}{ ICR (mg/kg b.w.) } \\
\hline & Control & 250 & 500 & 1000 \\
\hline White blood cells $\left(\mathrm{X} 10^{3} / \mu \mathrm{L}\right)$ & $18.300 \pm 0.900$ & $15.830 \pm 0.419^{\text {ns }}$ & $18.530 \pm 1.934^{\mathrm{ns}}$ & $19.800 \pm 1.400^{\text {ns }}$ \\
\hline Lymphocytes (\%) & $82.850 \pm 5.250$ & $73.170 \pm 11.690^{\mathrm{ns}}$ & $65.800 \pm 1.900^{*}$ & $63.230 \pm 3.150^{*}$ \\
\hline Granulocytes (\%) & $16.000 \pm 2.384$ & $23.000 \pm 1.277^{*}$ & $23.300 \pm 2.000^{*}$ & $24.350 \pm 2.850^{*}$ \\
\hline Red blood cells (X 106 / $\mu \mathrm{L})$ & $5.150 \pm 0.694$ & $5.483 \pm 0.131^{\mathrm{ns}}$ & $5.767 \pm 0.754^{\mathrm{ns}}$ & $5.187 \pm 0.838^{\mathrm{ns}}$ \\
\hline Haemoglobin $(\mathrm{g} / \mathrm{dL})$ & $17.000 \pm 1.200$ & $15.930 \pm 1.012^{\mathrm{ns}}$ & $17.000 \pm 0.500^{\text {ns }}$ & $14.630 \pm 1.635^{\mathrm{ns}}$ \\
\hline Hematocrit (\%) & $29.530 \pm 1.351$ & $29.100 \pm 1.253^{\mathrm{ns}}$ & $29.050 \pm 1.650^{\mathrm{ns}}$ & $27.590 \pm 1.960^{\mathrm{ns}}$ \\
\hline Mean corpuscular volume (fL) & $82.530 \pm 3.057$ & $78.950 \pm 4.122^{\mathrm{ns}}$ & $81.650 \pm 3.450^{\text {ns }}$ & $80.350 \pm 4.450^{\text {ns }}$ \\
\hline Mean corpuscular $\mathrm{Hb}(\mathrm{pg})$ & $34.170 \pm 5.44$ & $33.470 \pm 6.130^{\mathrm{ns}}$ & $32.000 \pm 5.900^{\mathrm{ns}}$ & $33.100 \pm 4.700^{\mathrm{ns}}$ \\
\hline MCHC (g/dL) & $40.850 \pm 2.550$ & $40.600 \pm 1.900^{\mathrm{ns}}$ & $50.000 \pm 2.300^{*}$ & $52.200 \pm 2.010^{*}$ \\
\hline RDWCV (\%) & $18.000 \pm 2.200$ & $17.570 \pm 2.203^{\text {ns }}$ & $19.070 \pm 1.602^{\text {ns }}$ & $17.000 \pm 1.400^{\mathrm{ns}}$ \\
\hline RDWSD (fL) & $44.370 \pm 3.168$ & $43.430 \pm 3.350^{\text {ns }}$ & $65.250 \pm 4.750^{\mathrm{ns}}$ & $65.850 \pm 4.050^{\mathrm{ns}}$ \\
\hline Platelets (X $\left.10^{3} / \mu \mathrm{L}\right)$ & $737.000 \pm 60.000$ & $600.0 \pm 65.200^{\mathrm{ns}}$ & $650.300 \pm 58.8000^{n s}$ & $651.300 \pm 60.500^{n s}$ \\
\hline Mean platelet volume (fL) & $11.650 \pm 0.650$ & $11.530 \pm 0.650^{\text {ns }}$ & $11.400 \pm 0.600^{\mathrm{ns}}$ & $10.730 \pm 0.611^{\mathrm{ns}}$ \\
\hline Platelet distribution width ( $\mathrm{fL}$ ) & $11.400 \pm 0.800$ & $11.000 \pm 0.700^{\mathrm{ns}}$ & $9.850 \pm 1.150^{\mathrm{ns}}$ & $10.200 \pm 0.400^{\mathrm{ns}}$ \\
\hline Plateletcrit (\%) & $0.840 \pm 0.180$ & $0.735 \pm 0.205^{\mathrm{ns}}$ & $0.870 \pm 0.040^{\mathrm{ns}}$ & $0.935 \pm 0.165^{\mathrm{ns}}$ \\
\hline
\end{tabular}

Results were expressed as Mean \pm SEM for $n=5$ per group. *:Significantly different from the control at $p<0.05$

MCHC Mean corpuscular Haemoglobin concentration, RDWCV Red blood cells distribution width_CV, RDWSD Red blood cells distribution width_SD, ns non significative, ICR methanol extract of the roots of Imperata cylindrica

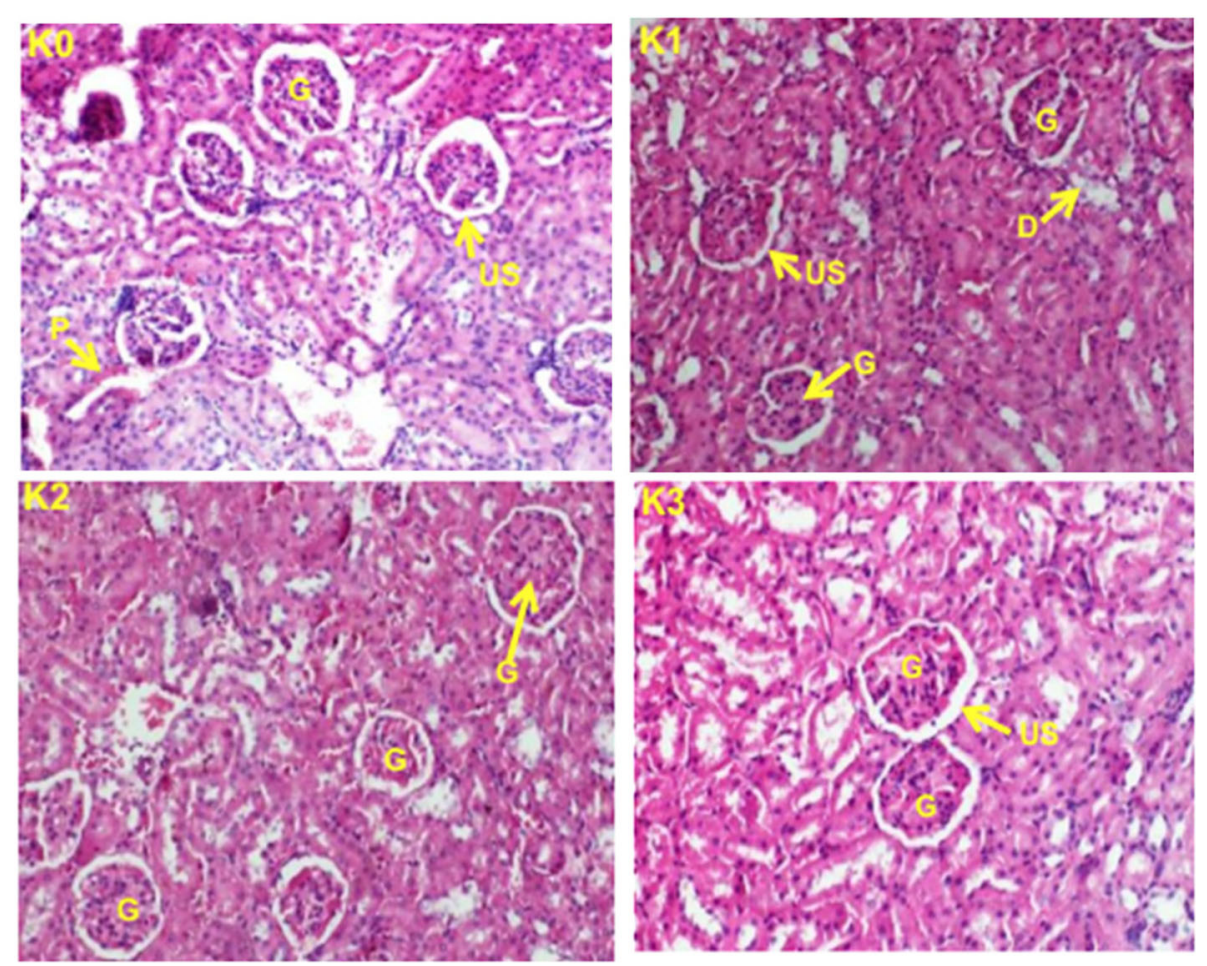

Fig. 3 Kidney sections showing the effect of ICR after 30 days of sub-chronic toxicity study in females rats: (K0) Control group; (K1) 250 mg/kg; (K2) 500 mg/kg and (K3) 1000 mg/kg. Indicators: G: Glomerula, D: Distal tubule, P: Proximal tubule, US:Urinary space 


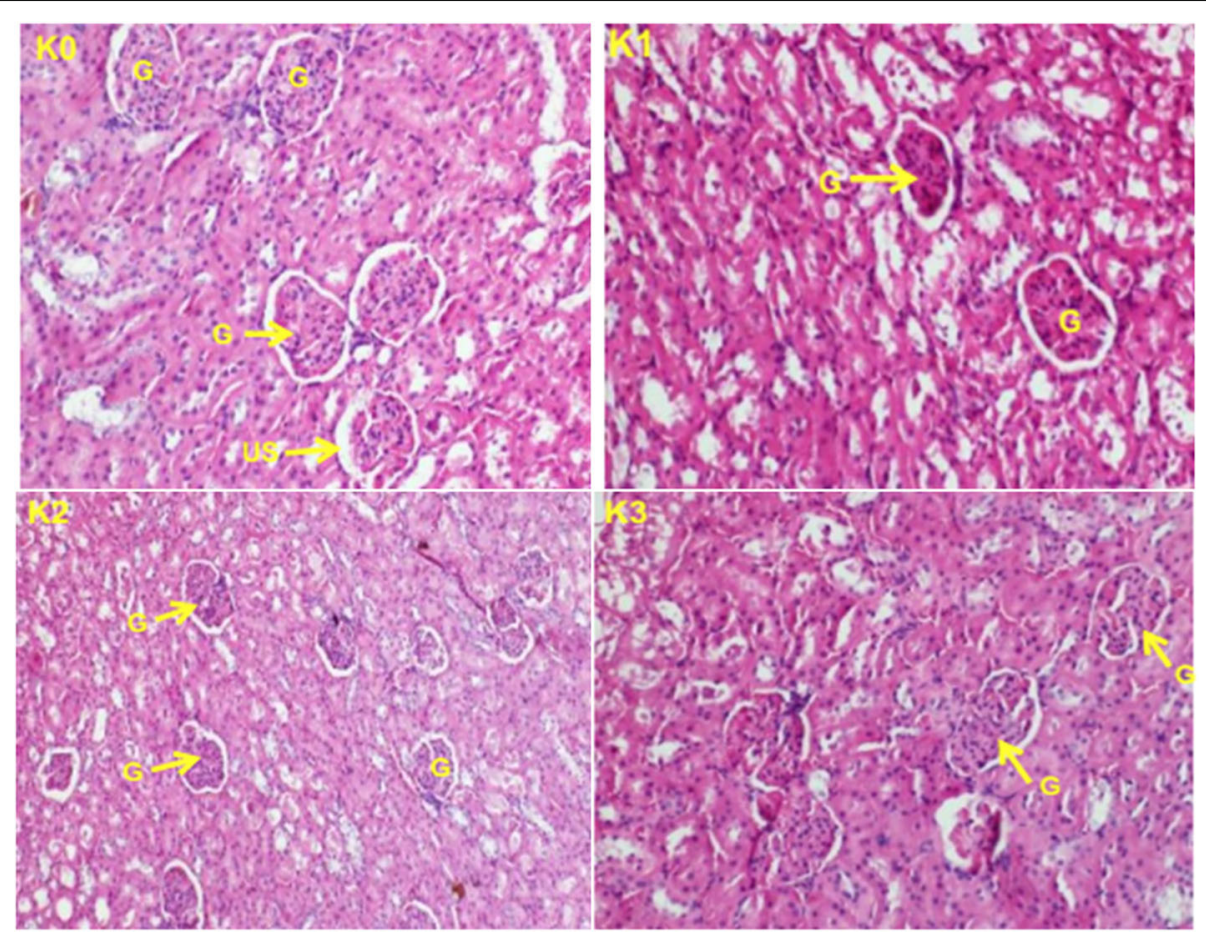

Fig. 4 Kidney sections showing the effect of ICR after 30 days of sub-chronic toxicity study in males rats: (K0) Control group; (K1) 250 mg/kg; (K2) $500 \mathrm{mg} / \mathrm{kg}$ and (K3) $1000 \mathrm{mg} / \mathrm{kg}$. Indicators: B: Glomelura and US: Urinary space

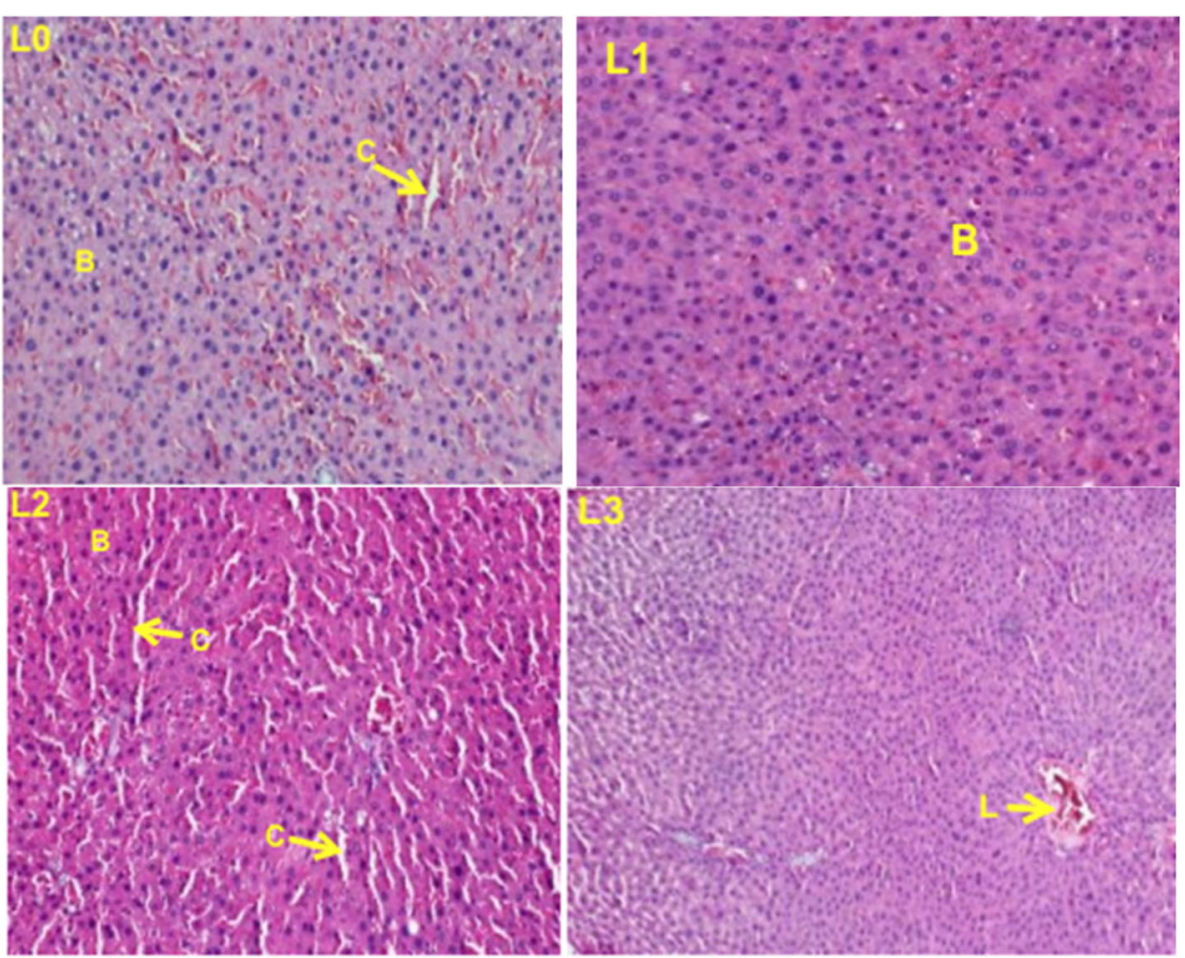

Fig. 5 Liver sections showing the effect of ICR after 30 days of sub-chronic toxicity study in females rats: (LO) Control group; (L1) 250 mg/kg; (L2) $500 \mathrm{mg} / \mathrm{kg}$ and (L3) $1000 \mathrm{mg} / \mathrm{kg}$. Indicators: B: Hepatocytes, C: Leukocytes infiltration, L: Cell lysis 

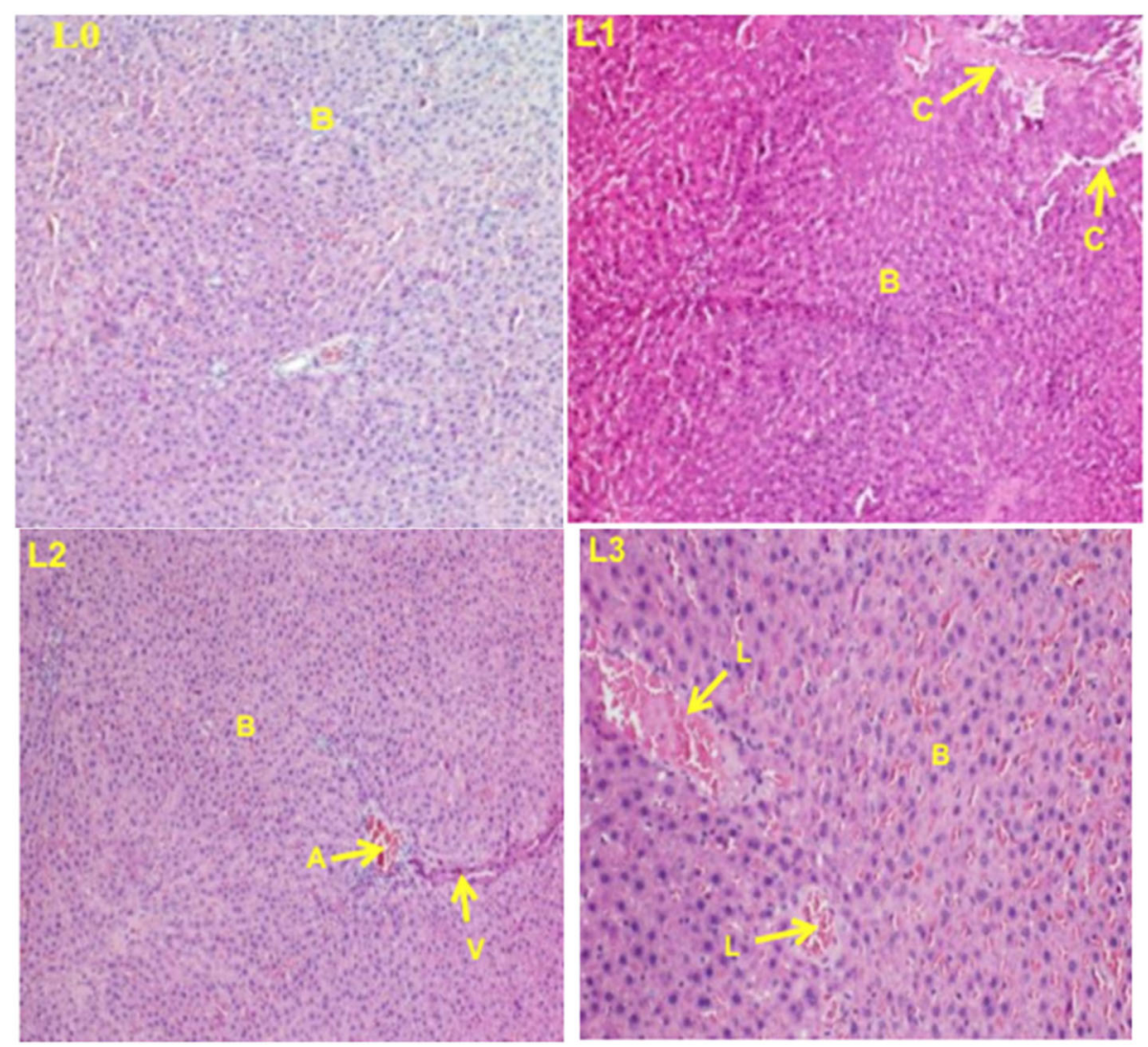

Fig. 6 Liver sections showing the effect of ICR after 30 days of sub-chronic toxicity study in males rats: (LO) Control group; (L1) 250 mg/kg; (L2) $500 \mathrm{mg} / \mathrm{kg}$ and (L3) $1000 \mathrm{mg} / \mathrm{kg}$. Indicators: B: Hepatocytes, C: Leukocyte infiltration, V: Centrilobular vein. L: Cell lysis

roots of Imperata cylindrica in the present work comes to the fact they are abundantly used as spices, commercially available in African Market.

\section{Conclusion}

The acute toxicity results of ICR indicated an $\mathrm{LD}_{50}$ greater than the $5000 \mathrm{mg} / \mathrm{Kg}$ b.w. dose, suggesting that root methanol extract of this plant is non-toxic and could be used safely at single administration. However, prolonged oral administration of the methanol extract of ICR at 250 and $500 \mathrm{mg} / \mathrm{Kg}$ b.w. can lead to the variation of some biochemical and hematological parameters without causing damage of vital organs involved in the metabolism and excretion of xenobiotics from the body. At $1000 \mathrm{mg} / \mathrm{Kg}$ b.w., ICR can cause slight liver damage. Therefore, safety measures should be taken before oral ingestion of ICR for therapeutic purposes or for other uses, and prolonged use should be discouraged at high doses.

\section{Supplementary information}

Supplementary information accompanies this paper at https://doi.org/10. 1186/s12906-020-03064-6.

Additional file 1.

\section{Abbreviations}

ALT: alanine aminotransferase; AST: aspartate aminotransferase; b-w-: body weight; EDTA: ethylene diamine tetra-acetic acid; HCT: Hematocrit; $\mathrm{Hb}$ : hemoglobin; HDL: high density lipoprotein; ICR: methanol extract of the roots of Imperata cylindrica; MCHC: mean corpuscular hemoglobin concentration; MCV: mean corpuscular volume; MCH: mean corpuscular hemoglobin; LD $_{50}$ : medium lethal dose; LDL: low density lipoprotein; PLT: platelets; RBC: red blood cells; TG: triglyceride; TC: total cholesterol

\section{Acknowledgments}

We acknowledge Dr. Norbert Kodjio, Mr. Jean DD Sokoudjou and Mr. Alain Fowa for providing some facilities for this study.

\section{Authors' contributions}

PN carried out the study; ATM and VK designed the experiments. PN and AMN analyzed data; PN, AMN, ATM and VK wrote the manuscript; ATM and VK supervised the work; all authors read and approved the final manuscript.

\section{Funding}

No funding.

\section{Availability of data and materials}

All data generated or analyzed during this study are included in this published article.

\section{Ethics approval and consent to participate}

All the experimentation was carried out in strict accordance with the established guidelines on the use of experimental animals. All sections of this report adhere to the ARRIVE Guidelines for reporting animal research [17]. A completed ARRIVE guidelines checklist is included in Checklist S1. 


\section{Consent for publication}

Not applicable.

\section{Competing interests}

VK is a Section Editor of BMC Complementary and Alternative Medicine; ATM is an Associate Editor of BMC Complementary and Alternative Medicine; all the other authors declare that they have no competing interests.

Received: 11 March 2020 Accepted: 30 August 2020

Published online: 10 September 2020

\section{References}

1. Gibbons S. Phytochemicals for bacterial resistance strengths, weaknesses and opportunities. Planta Med. 2008:6:594-602..

2. Sharifi-Rad J, Sharifi-Rad M, Saledhi B, Iriti M, et al. In vitro and in vivo assessment of free radical scavenging and antioxidant activities of Veronica persica Poir. J Mol Cell Biol. 2018;64(8):57-64

3. Salehi B, Sharopov F, Martorell M, Rajkovic J, et al. Phytochemicals in helicobacter pylori infections: what are we doing now? Int J Mol. 2018;9(8):2361.

4. Park JH. Medicinal Plants of Korea. Seoul: Shinil Publishing Co; 2004. p. 101

5. Voukeng Kl, Kuete V, Dzoyem JP, et al. Antibacterial and antibioticpotentiation activities of the methanol extract of some Cameroonian spices against gram-negative multi-drug resistant phenotypes. BMC Res Notes. 2012;5:299.

6. Dzoyem JP, Tchuenguem JR, Kuiate J-R, et al. In vitro and in vivo antifungal activities of selected Cameroonian dietary spices. BMC Complement Altern Med. 2014;14:58

7. Oyindamola O, Abiodun GO, Gbotosho GO, et al. Antitrypanosomal activity of some medicinal plants from Nigerian ethnomedicine. Parasitol Res. 2012; 110:521-6.

8. Kuete V, Sandjo LP, Wiench B, Efferth $T$, et al. Cytotoxicity and modes of action of four Cameroonian dietary spices ethno-medically used to treat cancers: Echinops giganteus, Xylopia aethiopica, Imperata cylindrica and Piper capense. J Ethnopharmacol. 2013;149:245-53.

9. Keshava R, Muniyappa N, Gope R, et al. Anti-Cancer effects of Imperata cylindrica leaf extract on human Oral squamous carcinoma cell line SCC-9 in vitro, Asian Pac. J cancer Prev. 2016;17:1891-8.

10. Kwok AH, Wang YY, Wing SH. Cytotoxic and pro-oxidative effects of Imperata cylindrica aerial part ethyl acetate extract in colorectal cancer in vitro. Phytomed. 2016;23:558-6.

11. Kuete V, Krusche B, Youns M, Voukeng I, Fankam AG, Tankeo S, Lacmata S, Efferth T. Cytotoxicity of some Cameroonian spices and selected medicinal plant extracts. J Ethnopharmacol. 2011;134:803-12.

12. Matsunaga K, Shibuya M, Ohizumi Y. Cylindrene, a novel sesquiterpenoid from Imperata cylindrica with inhibitory activity on contractions of vascular smooth muscle. J Nat Prod. 1994b;57:1183-4.

13. Matsunaga K, Shibuya M, Ohizumi Y, Graminone B. A novel lignan with vasodilative activity from Imperata cylindrica. J Nat Prod. 1994c;57:1734-6.

14. Matsunaga K, Shibuya M, Ohizumi Y, Graminone B. A novel phenolic compound with platelet aggregation inhibitory activity from Imperata cylindrica. J Nat Prod. 1995;58:138-9.

15. Patel S, Mukesh K, Daharwal SJ, Manju SR, et al. Plant toxins: an overview. Res J Pharmacology and Pharm. 2013;5:283-8.

16. Burke WA. Skin diseases in farmers in: Langley, RL, McLymore, RL, Meggs, WJ and Roberson, GT, editors safety and health in agriculture, forestry, and fisheries. Rockville, MD: Government Institutes; 1997.

17. Kilkenny C, Browne WJ, Cuthill IC, Emerson M, Altman DG. Improving bioscience research reporting: the ARRIVE guidelines for reporting animal research. PLoS Biol. 2010;8:e1000412.

18. OECD. Guidelines for the testing of chemicals: Test № 425, Acute Oral Toxicity - Up-and-Down-Procedure; 2008. p. 1-29.

19. Gatsing D, Aliyu R, Kuiate J-R, Garba $\Vdash H$, et al. Toxicological evaluation of aqueous extract of Allium sativum bulbs on laboratory mice and rats. J Exp Biol. 2005;1:39-45.

20. OECD. Guidelines for the testing of chemicals, Test № 407, repeated dose 28-day oral toxicity study in rodents; 2008b. p. 1-14.

21. Caron S, Veilleux D, Lemieux, et al. Veterinary services Direction guidelines for users and for Animals house staff. Description of the blood procedures in rats. Canada: University of Laval; 2016.
22. Di-Fiore MSH. Atlas of human histology (2nd edn). Philadelphia: Lea and Febiger; 1963. p. 224.

23. Chunlaratthanaphorn S, Lertprasertsuke N, Srisawat U, et al. Acute and subchronic toxicity study of the water extract from root of Imperata cylindrica (Linn.) Raeusch. In rats. Songklanakarin J. Sci. Technol. 2007; 29:141-55.

24. Scharer $\mathrm{K}$. The effect of chronic underfeeding on organ weights of rats. How to interpret organ weight changes in cases of marked growth retardation in toxicity tests? Toxicol. 1997;7:45-56.

25. Sellers RS, Mortan D, Michael. Society of toxicologic pathology position paper: Organ weight recommendations for toxicology studies. Toxicol Pathol. 2007;35:751-5.

26. Greaves P. Histopathology of preclinical toxicity studies: interpretation and relevance in drug safety evaluation. New, York, NY: Academic Press; 2011.

27. Lee WM. Acute liver failure in the United States. Semin Liver Dis. 2003;23: 217-26.

28. Yamthe LR, David K, Ngadena YM. Acute and chronic toxicity studies of the aqueous and ethanol leaf extracts of Carica papaya Linn in Wistar rats. J Nat Prod. 2012;2:617-27.

29. Meyer D, Harvey JW. Hepatobiliary and skeletal muscle enzymes and liver function tests. In: Meyer D, Harvey JW, editors. Veterinary laboratory medicine: interpretation and diagnosis. St. Louis, MO: WB. Saunders Co; 2004. p. 169-92

30. Ramaiah K, Shashi. A toxicologist quide to the diagnostic interpretation of hepatic biochemical parameters. Food Chem Toxicol. 2007;45:1551-7.

31. Urine and serum creatinine and creatine clearance. https://www. medecineshoppe.ca.themedicineshoppepharmacy. Assessed 18 Mar 2019.

32. Mak-Mensah EE, Komlaga GO, Terlabi. Anti-hypertensive action of ethanolic extract of Imperata cylindrica leaves in animal models. J Med Plant Res. 2010:4:1486-91.

33. Ruslin MZ, Asmawi U, Rianse et al. Anti-hypertensive activity of Alang Alang (Imperata cylindrica (L.) Beauv. Root methanol extract on male Wistar rat. Int. J. Pharm. Sci. 2013; 4: 537-542.

34. Sulistyowati E, Hsu JH, Cheng YB, Chang FR, et al. Indonesian herbal medicine prevents hypertension-induced left ventricular hypertrophy by diminishing NADPH oxidase dependent oxidative stress. Oncotarget. 2017;8: 86784-98.

35. Bello, Bakkouri AS, Tabana YM, et al. Acute and Sub-Acute Toxicity Evaluation of the Methanol Extract of Alstonia scholaris Stem Bark. Med. Sci. 2014;4:4.

36. Mbagwu HOC, Olufunmilayo O, Adeyemi SJO, Offor SJ. Acute and subchronic toxicity studies of the aqueous extract of Mezoneuron benthamianum Baill (Caesalpiniaceae). J Environ Sci Toxicol Food Technol. 2016:10:61-6.

\section{Publisher's Note}

Springer Nature remains neutral with regard to jurisdictional claims in published maps and institutional affiliations.

\section{Ready to submit your research? Choose BMC and benefit from:}

- fast, convenient online submission

- thorough peer review by experienced researchers in your field

- rapid publication on acceptance

- support for research data, including large and complex data types

- gold Open Access which fosters wider collaboration and increased citations

- maximum visibility for your research: over $100 \mathrm{M}$ website views per year

At $\mathrm{BMC}$, research is always in progress.

Learn more biomedcentral.com/submissions 